Supporting Information

\title{
Direct Measurement of the Shear Strength of Fly Ash Powder Beds
}

\section{Nanami Aoki, ${ }^{1,2}$ Yohei Okada, ${ }^{*}$, and Hidehiro Kamiya $^{1}$}

${ }^{1}$ Department of Chemical Engineering, Tokyo University of Agriculture and Technology, 2-24-16 Naka-cho,

Koganei, Tokyo 184-8588, Japan

${ }^{2}$ Technology Department, Energy \& Environmental Group, Sumitomo Heavy Industries, Ltd., 25-9-7

Nishigotanda, Shinagawa, Tokyo 141-0031, Japan

Tel: (+81)-42-388-7068

Fax: (+81)-42-388-7068

E-mail: yokada@cc.tuat.ac.jp

Table of Contents

1. Additional Figures p. S2

2. Experimental Details for Measurements of Shear Strengths p. S11 


\section{Additional Figures.}
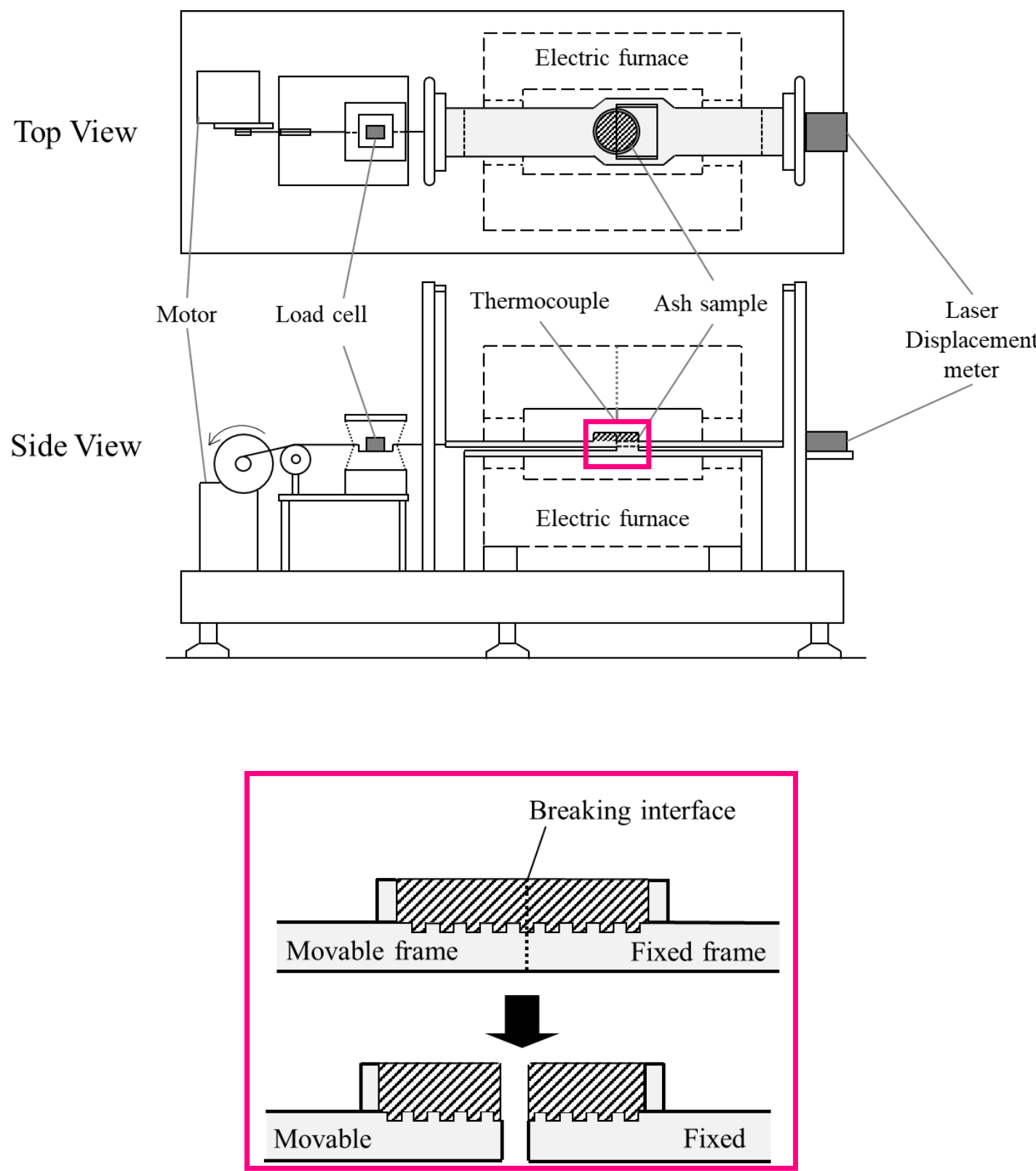

Figure S1. Schematic illustration of the tensile strength testing system. 

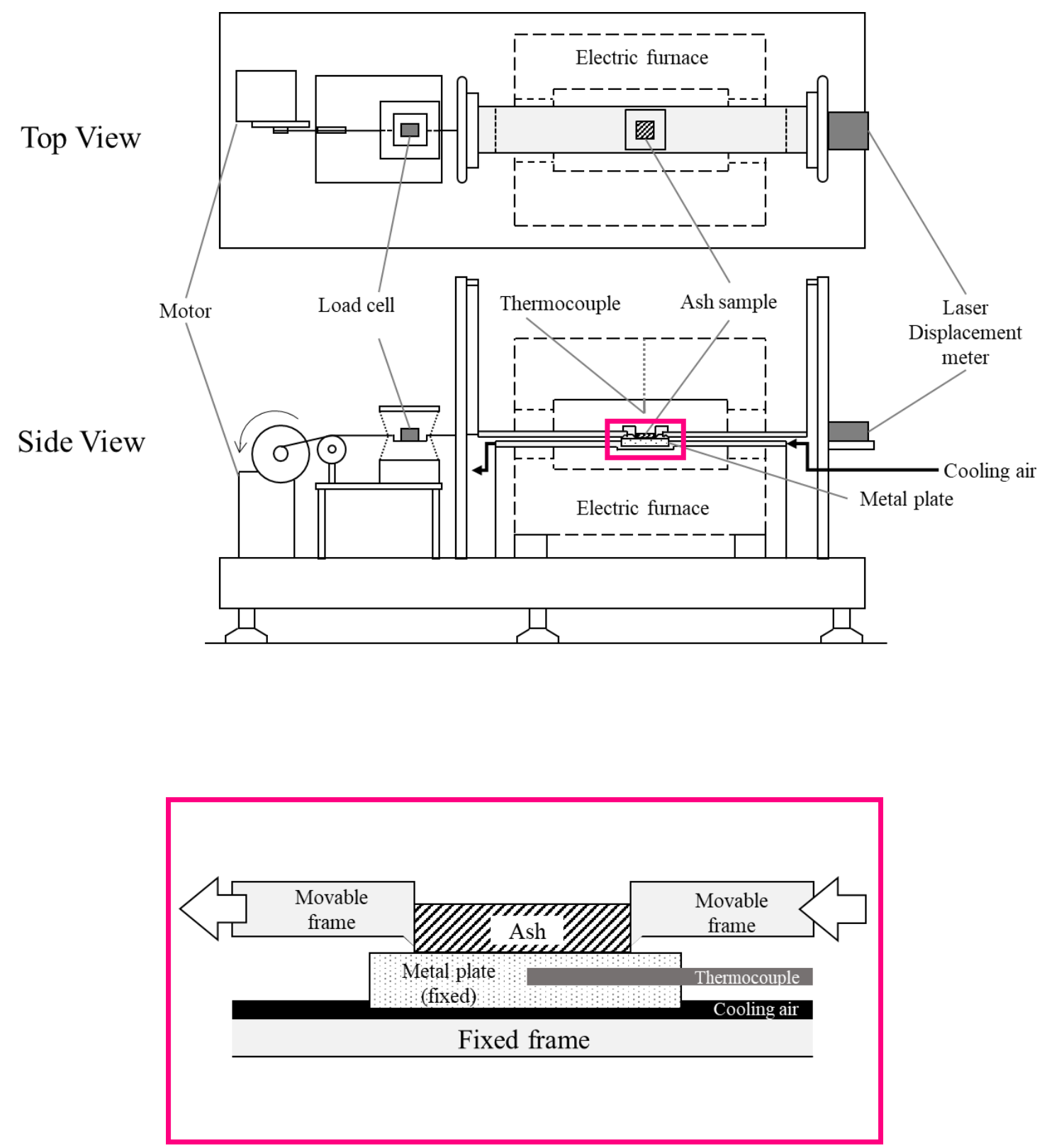

Figure S2. Schematic illustration of the shear strength testing system. 


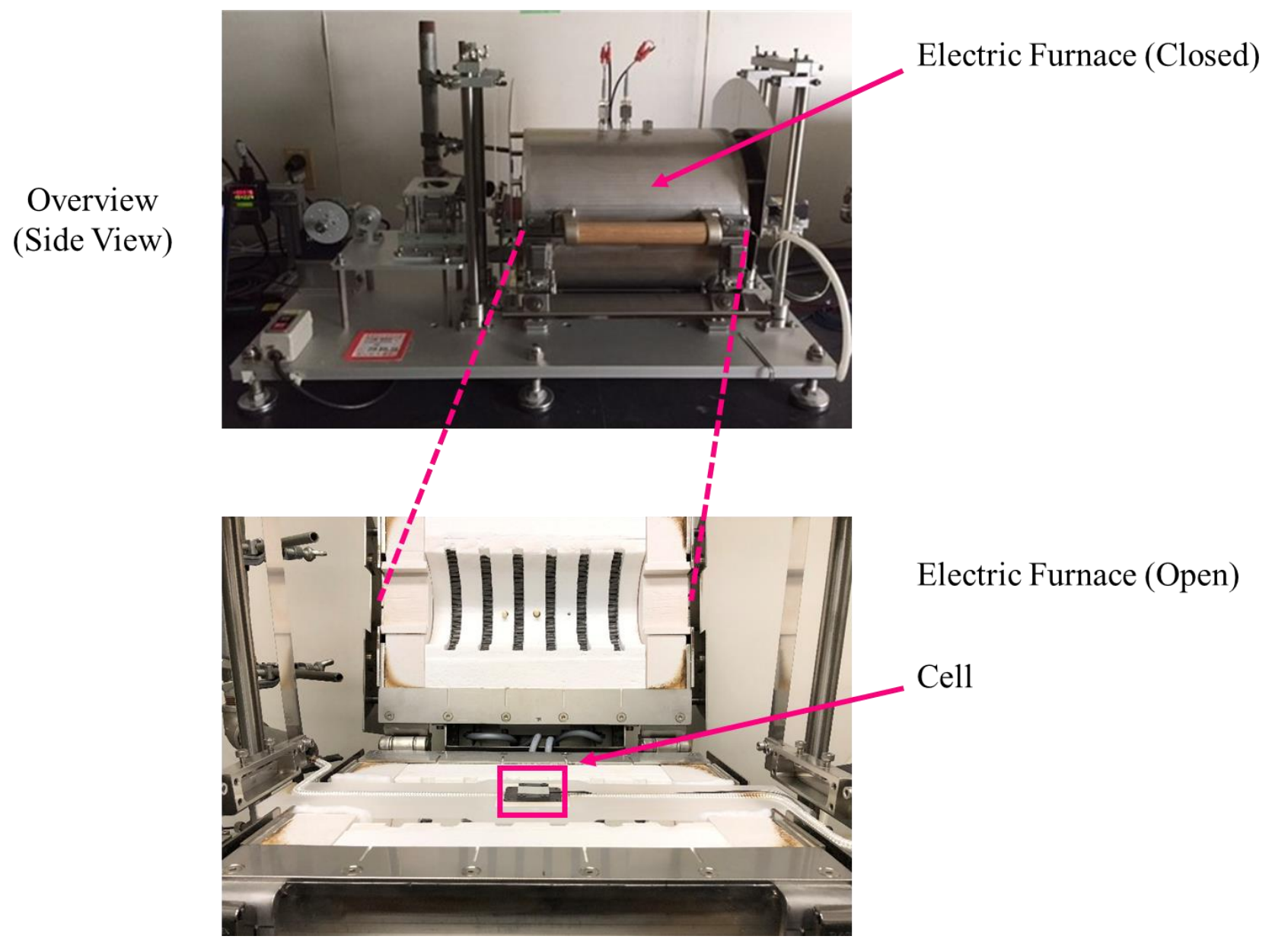

Figure S3. Photographs of the overview of shear strength testing system. 

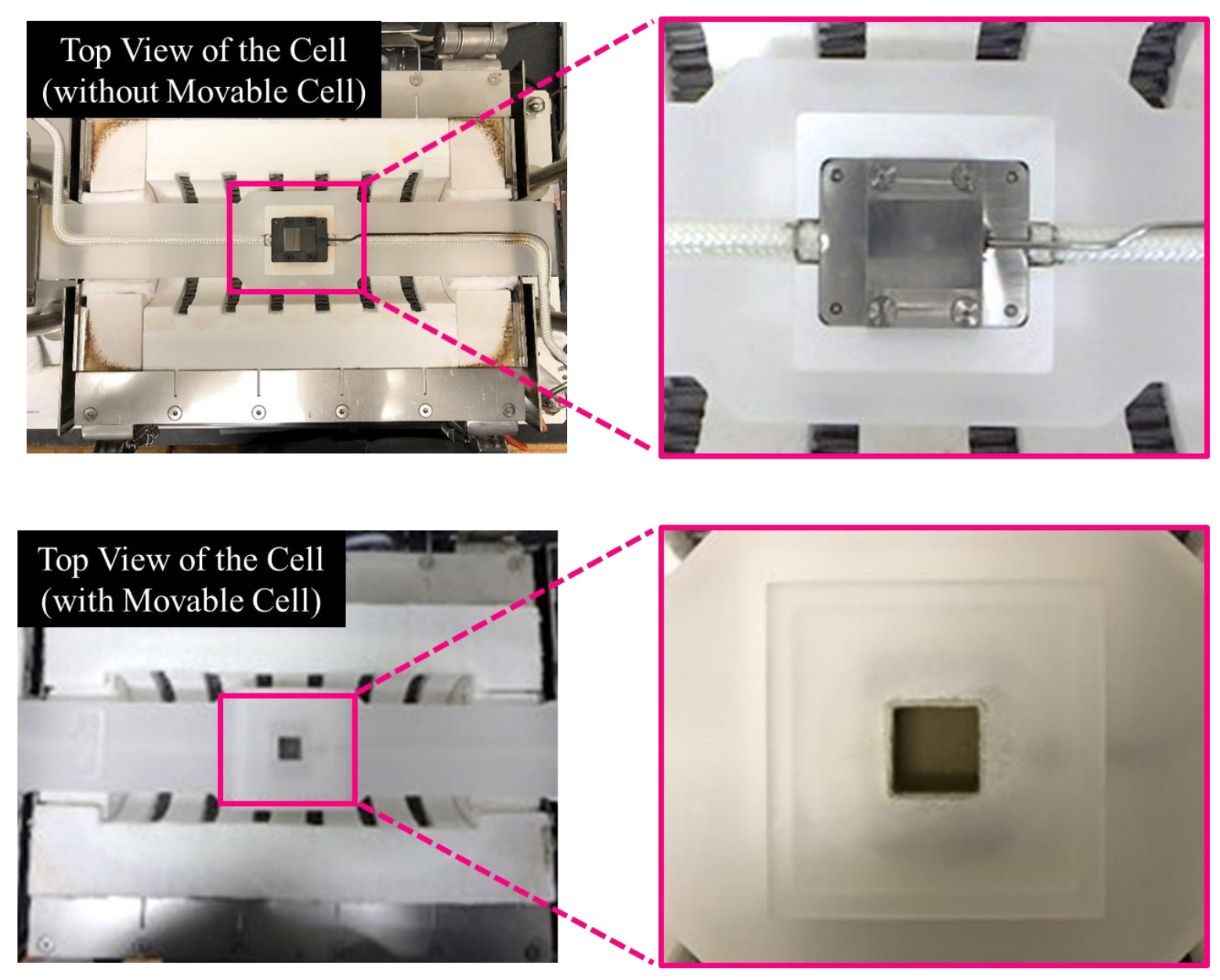

Figure S4. Photographs of the cell of the shear strength testing system. 


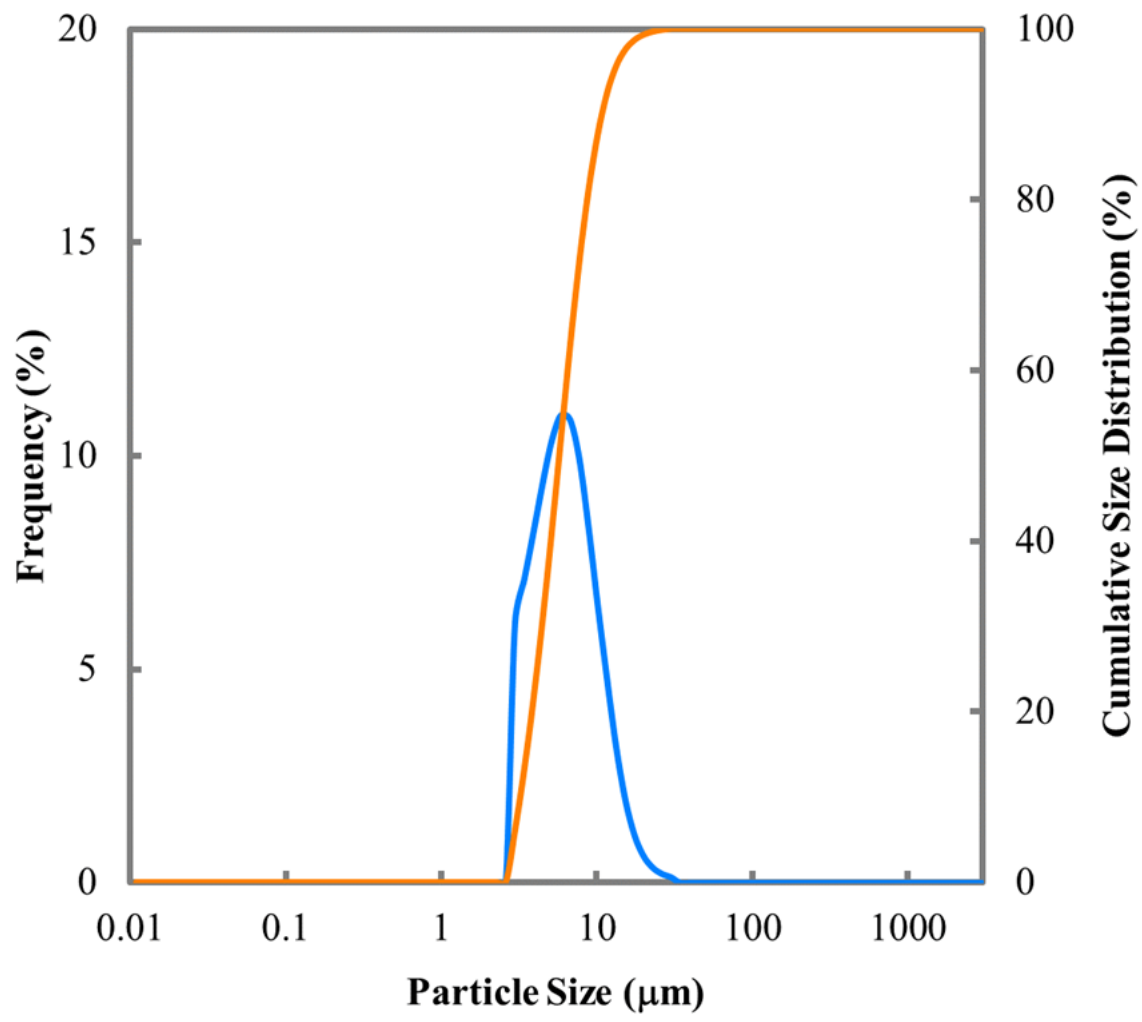

Figure S5. Size distribution of the fly ash sample. 


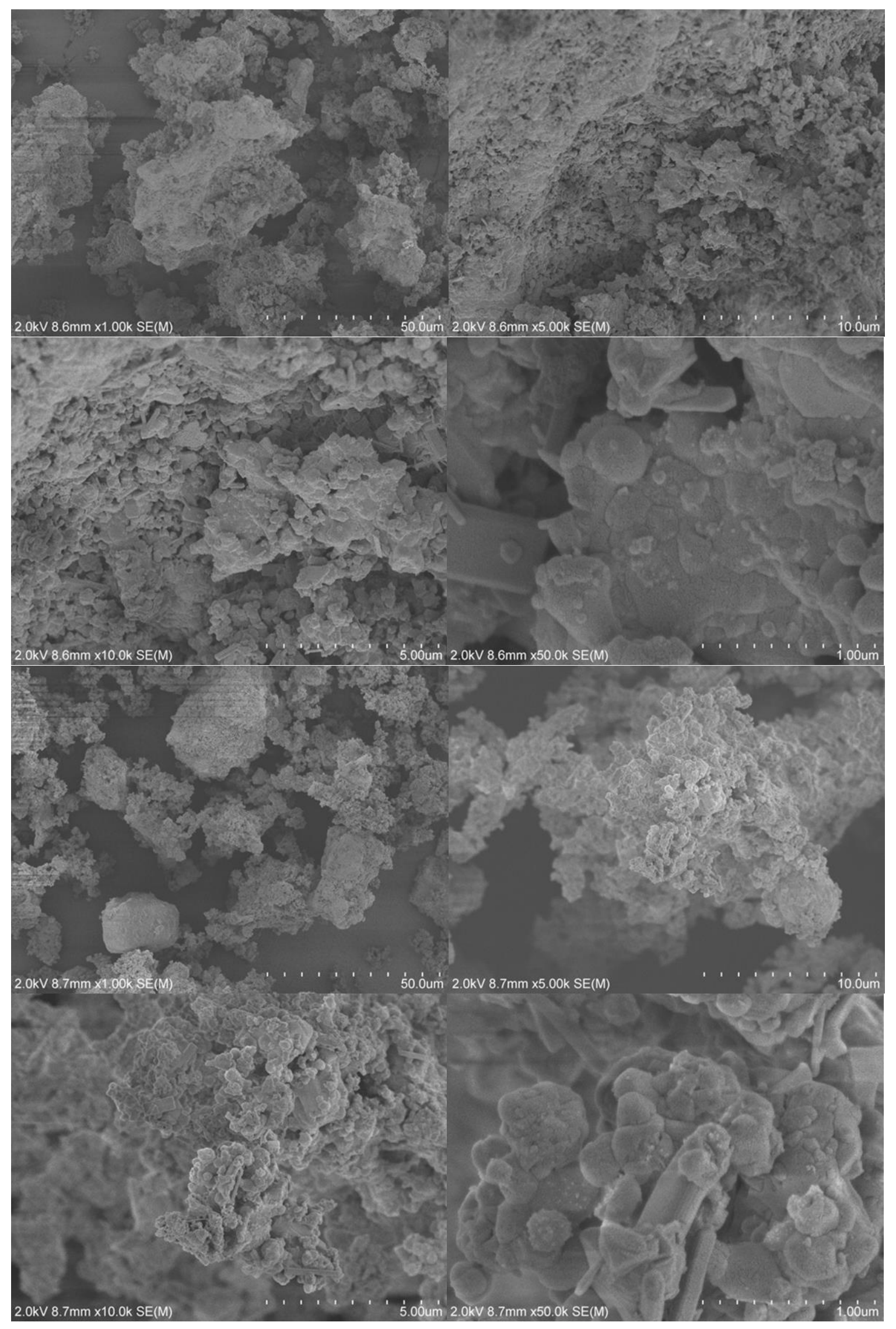

Figure S6. FE-SEM images of the of the fly ash sample. 


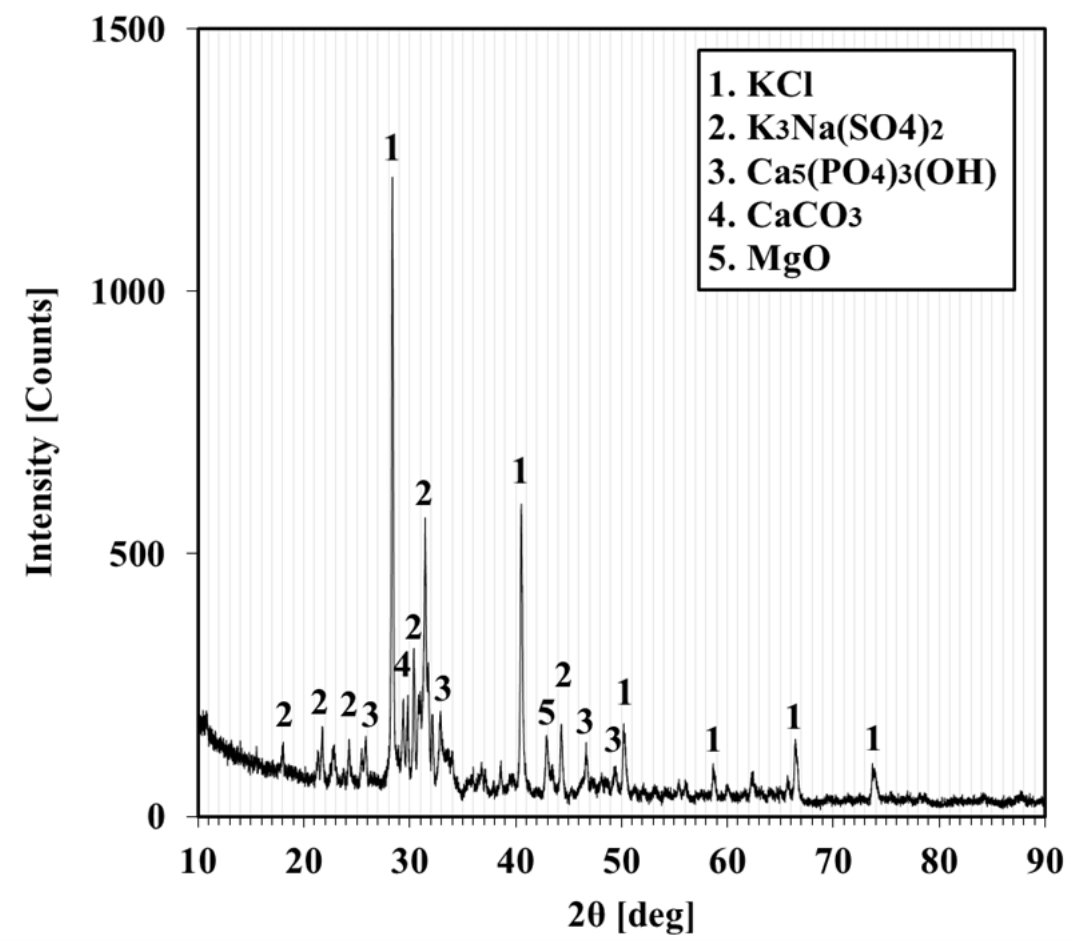

Figure S7. XRD pattern of the fly ash sample measured at room temperature. 


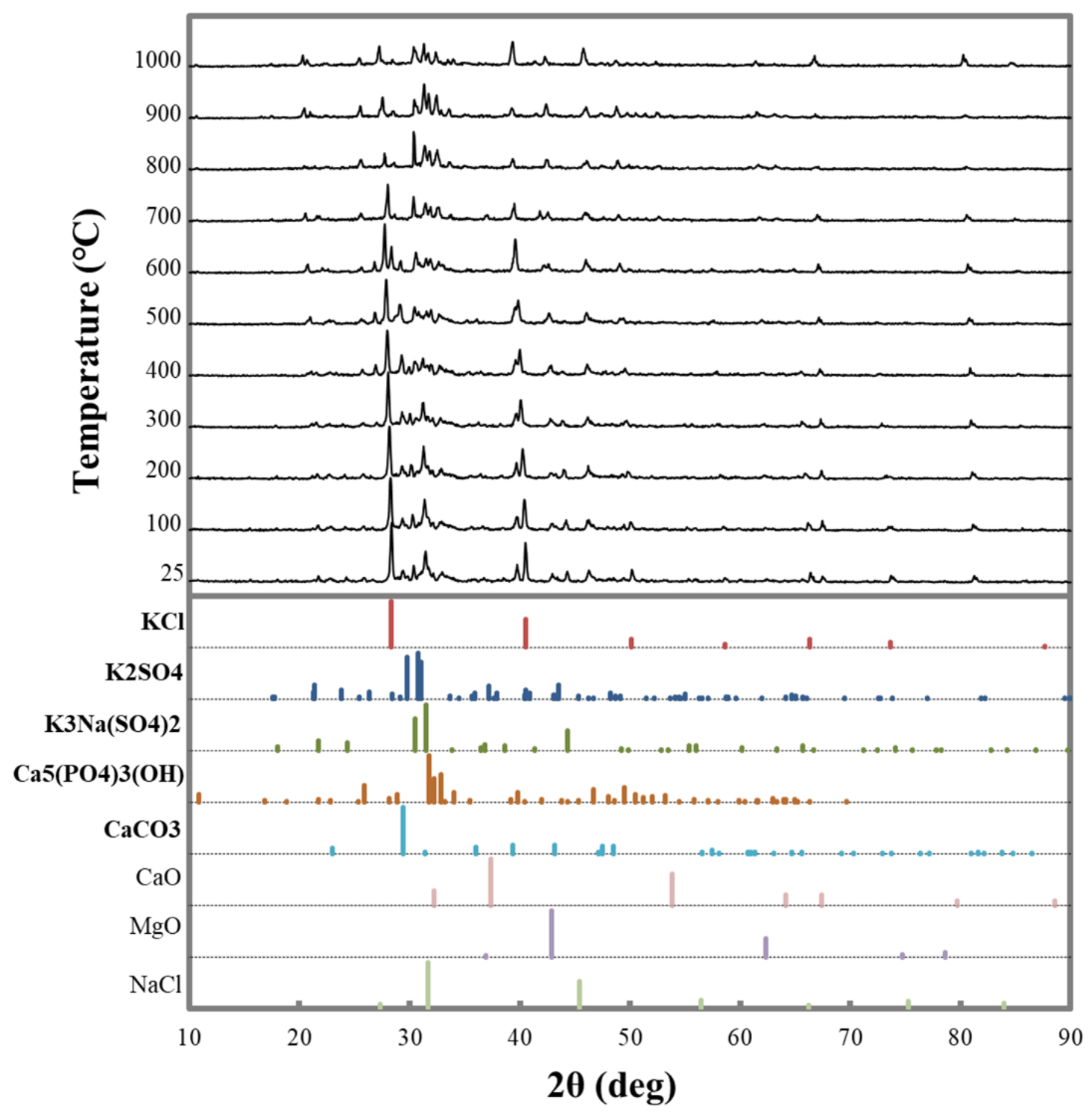

Figure S8. XRD patterns of the fly ash sample measured at varied temperatures. 


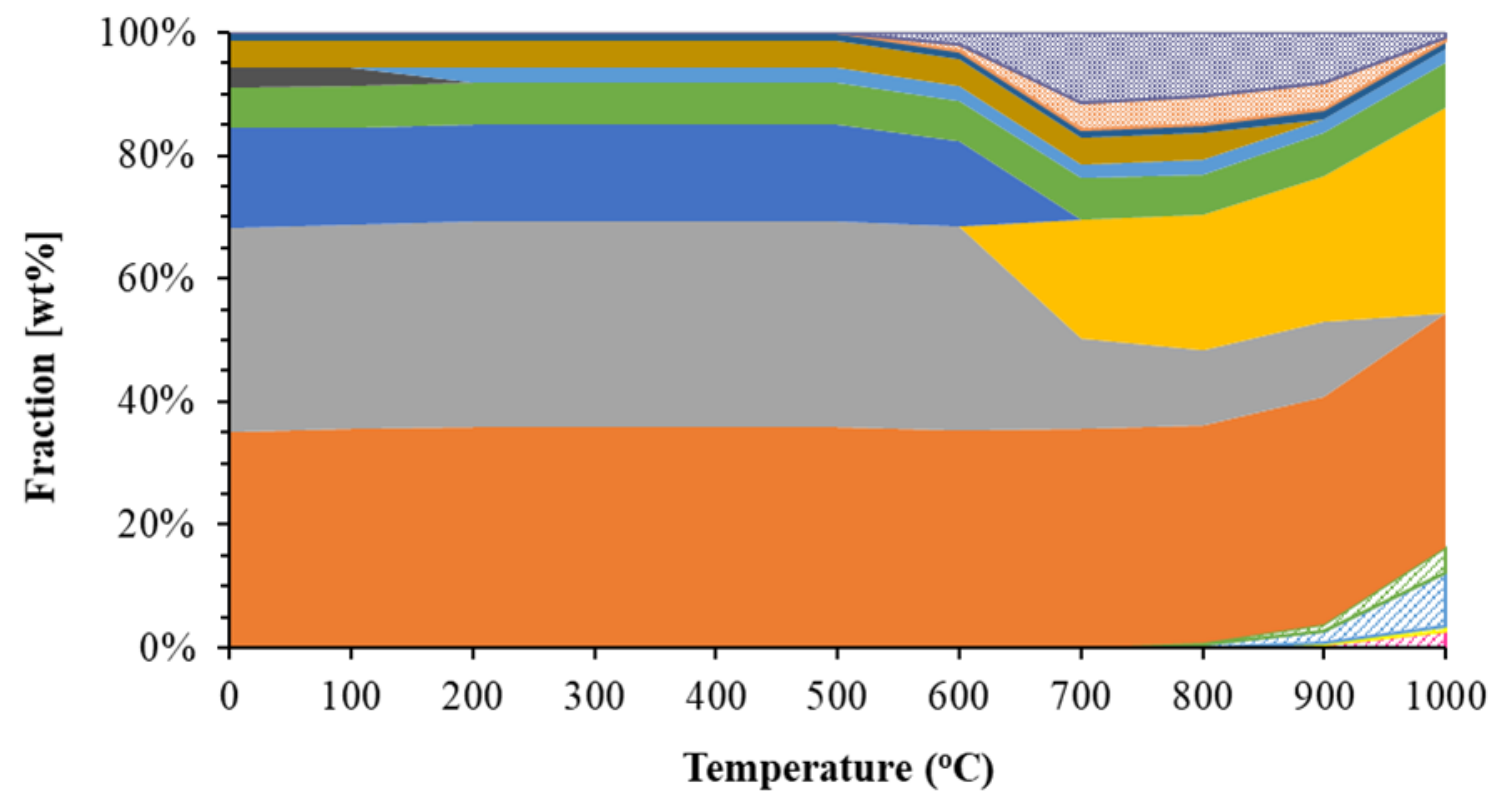

$\begin{array}{llll}\square \mathrm{NaCl}(\mathrm{g}) & \square(\mathrm{NaCl}) 2(\mathrm{~g}) & \square \mathrm{KCl}(\mathrm{g}) & \square(\mathrm{KCl}) 2(\mathrm{~g}) \\ \square \mathrm{Ca}(\mathrm{PO} 4) 2(\mathrm{~s}) & \square \mathrm{K} 3 \mathrm{Na}(\mathrm{SO} 4) 2(\mathrm{~s}) & \square \mathrm{K} 2 \mathrm{SO} 4(\mathrm{~s} 2) & \square \mathrm{KCl}(\mathrm{s}) \\ \square \mathrm{MgO}(\mathrm{s}) & \square \mathrm{CaO} 2(\mathrm{~s}) & \square \mathrm{CaO}(\mathrm{s}) & \square \mathrm{Ca} 2 \mathrm{SiO} 4(\mathrm{~s}) \\ \square \mathrm{C} 2 \mathrm{Fe} 2 \mathrm{O} 5(\mathrm{~s}) & \square \mathrm{NaCl}(\mathrm{SALTC \#}) & \square \mathrm{KCl}(\mathrm{SALTC \#}) & \end{array}$

Figure S9. Chemical components found in thermodynamic equilibrium calculations. 
2. Experimental Details.
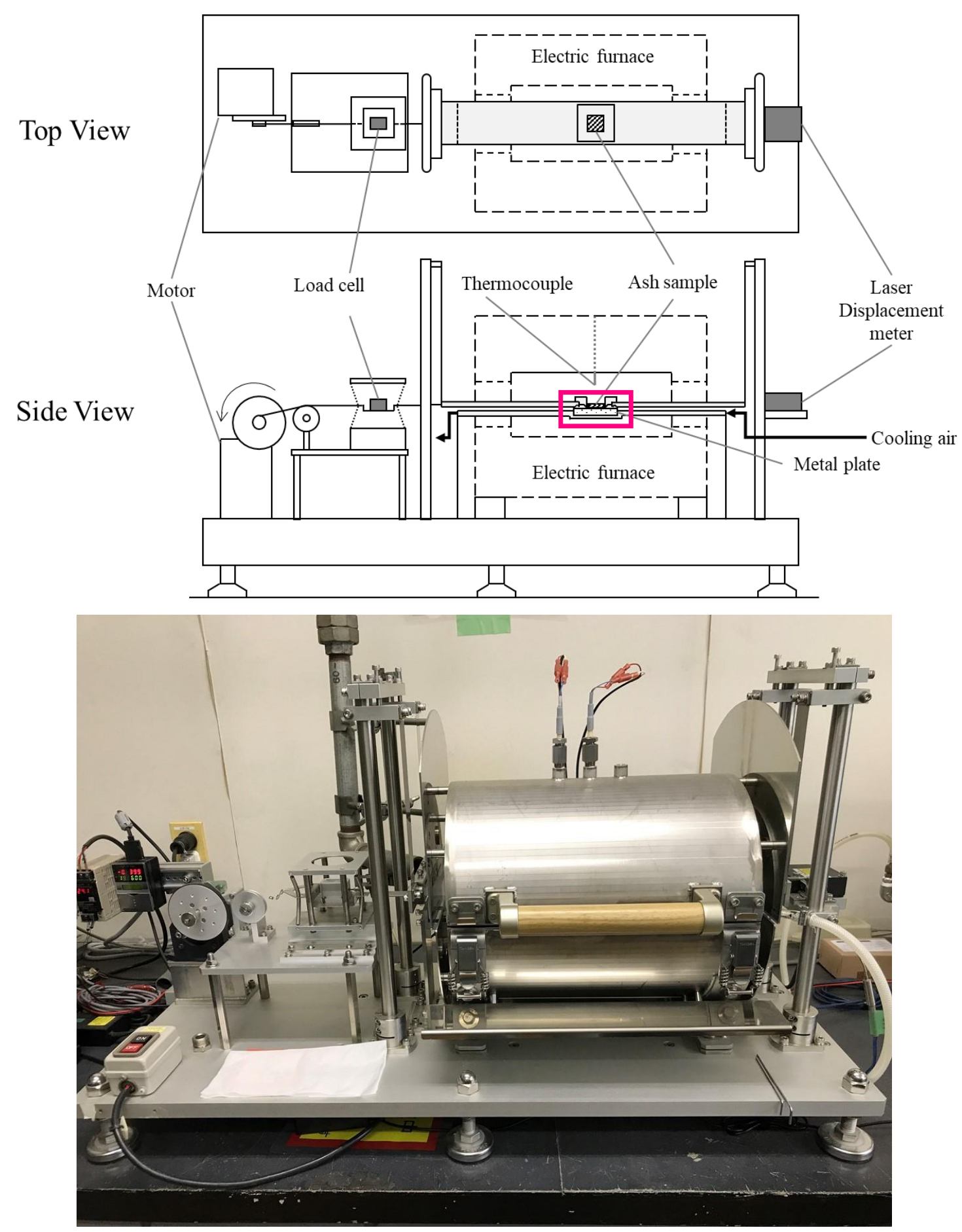

Figure S10. Overview of the shear strength testing system. 

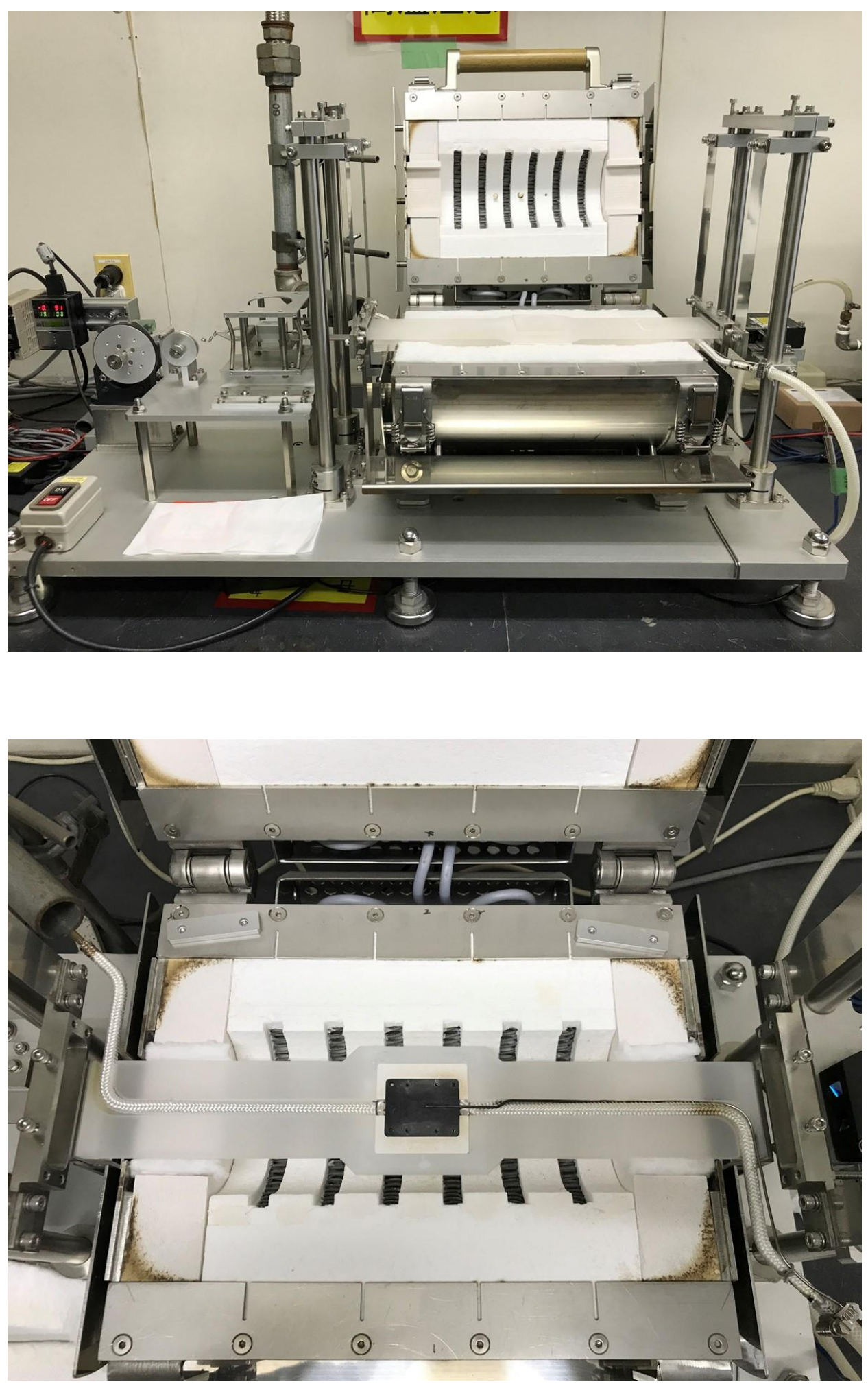

Figure S11. Open the electric furnace. Side view (above) and top view (below, inside of the electric furnace). 


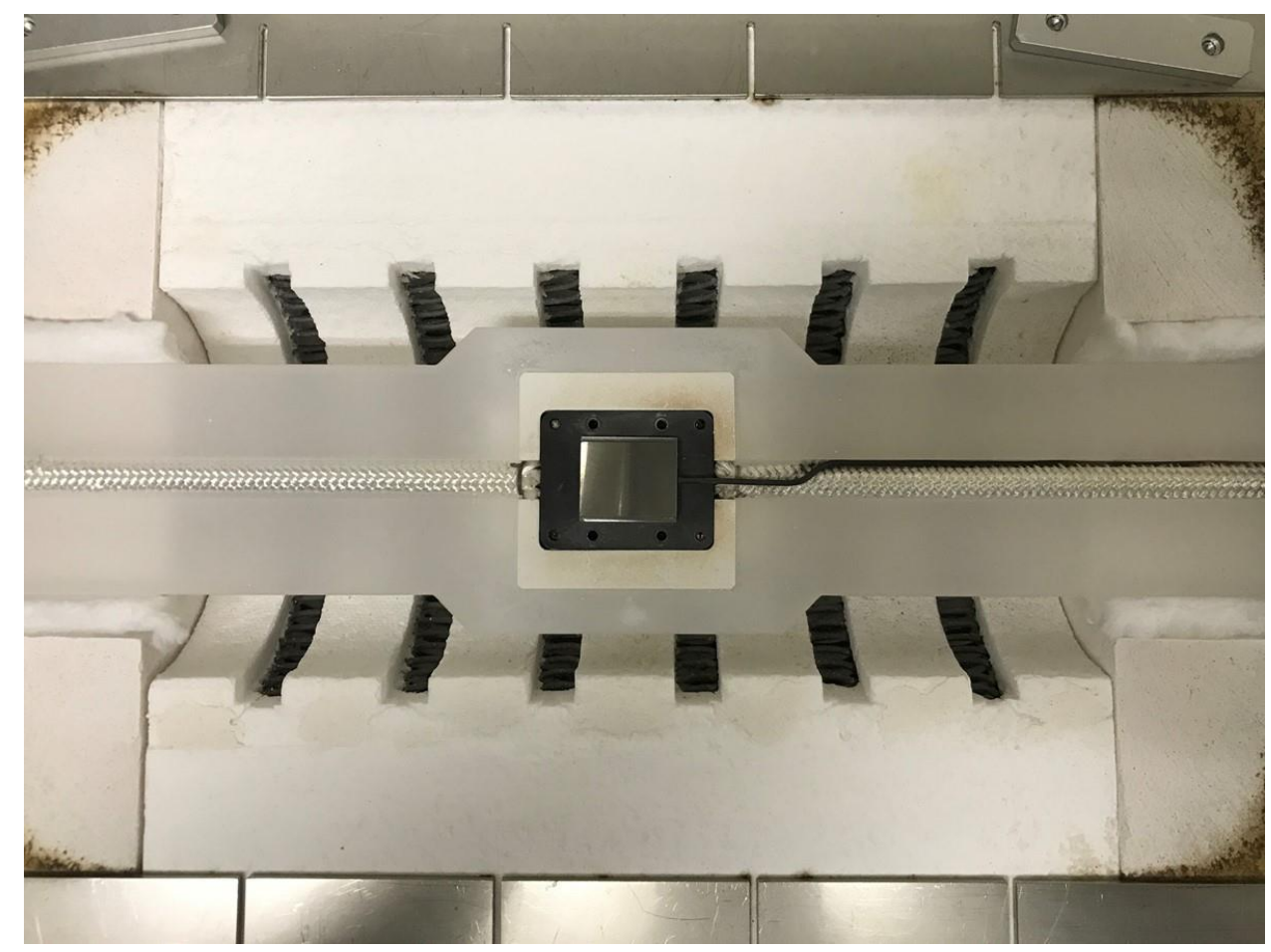

Figure S12. Set a metal plate. 


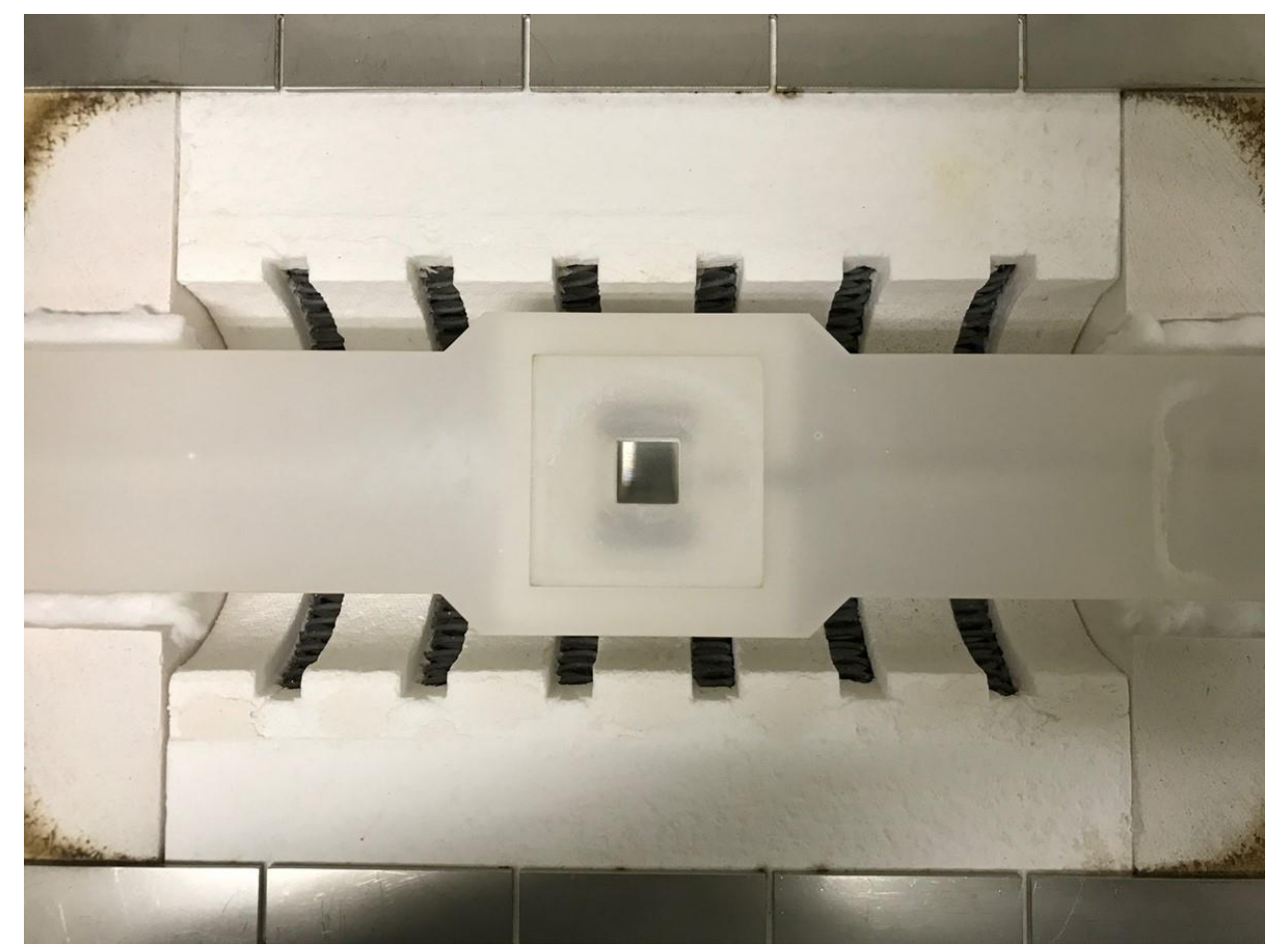

Figure S13. Set an integrated square cell (width/depth $15.8 \mathrm{~mm} \times$ height $16.0 \mathrm{~mm}$ ). 

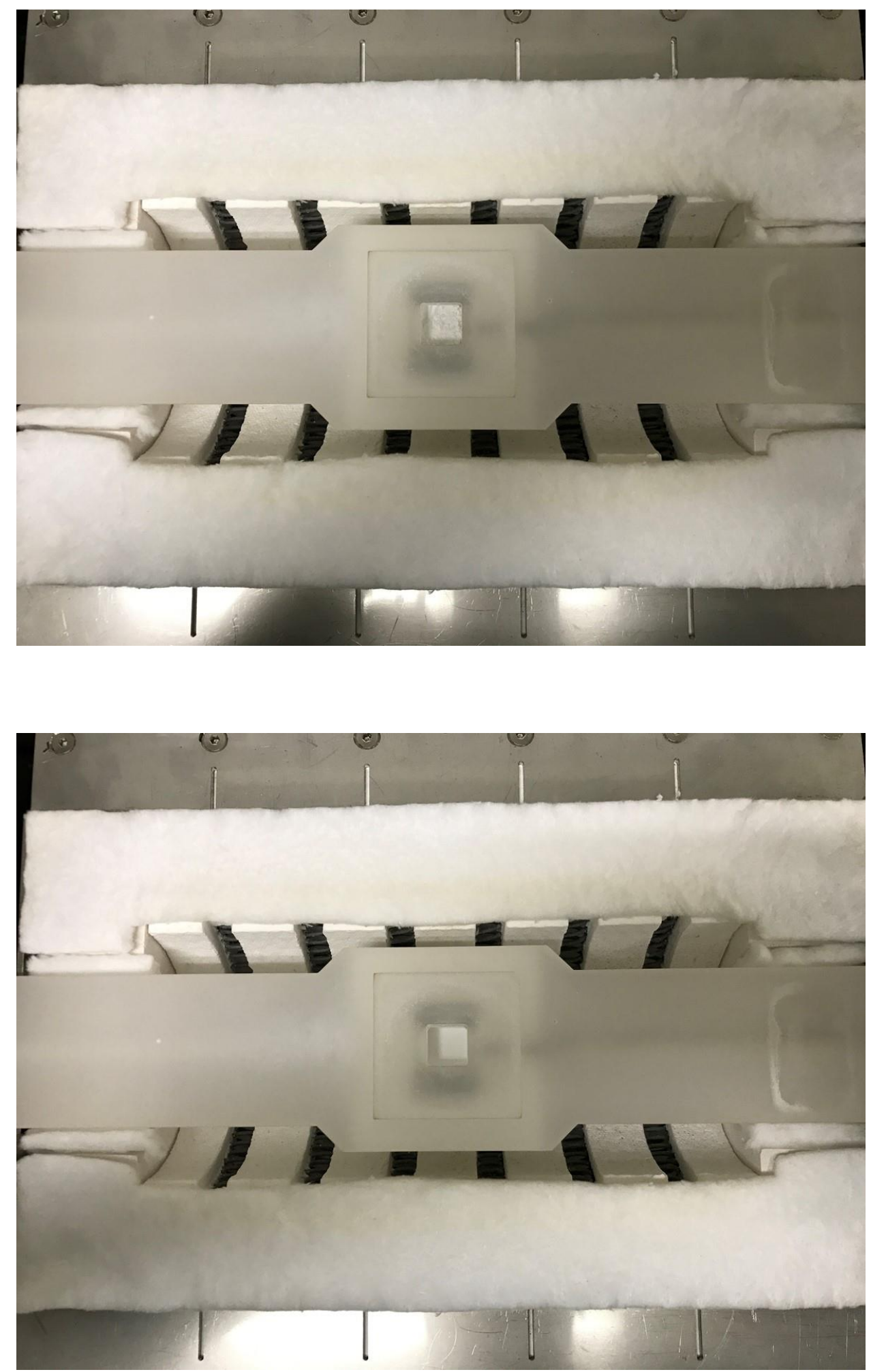

Figure S14. Pack fly ash samples $(0.82 \mathrm{~g})$ into the square cell and consolidate a powder bed by uniaxial pressing at $2.1 \mathrm{kPa}$ for $10 \mathrm{~min}$. Before consolidation (above) and after consolidation (below). 

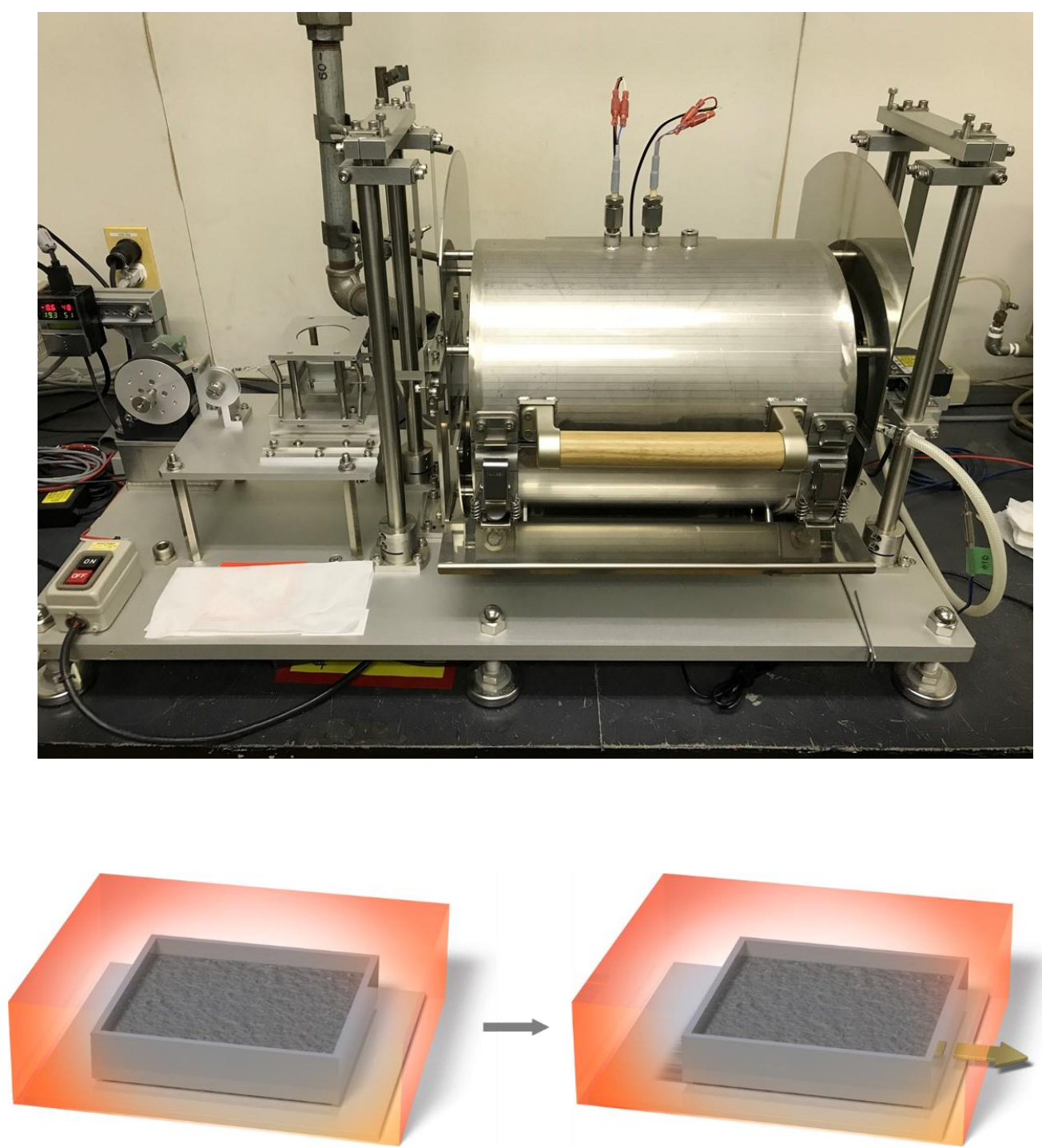

Figure S15. Close the electric furnace and start to heat $\left(10{ }^{\circ} \mathrm{C} / \mathrm{min}\right)$. When reached to a target temperature, the cell drags the powder bed on top of a metal plate in the furnace to measure shear strengths as a force of friction. 